Ind. Health, 1968, 6, 134.

\title{
METALLIC FUME GENERATED IN THE WELDING USING SILVER SOLDER
}

\author{
Noboru HARA, Katsunori HOMMA and Shigezi KOSHI \\ National Institute of Industrial Health, Kizuki-Sumiyoshi, Kawasaki
}

(Received April 23, 1968)

\begin{abstract}
The fume from silver solder was examined. It contained very high percentage of cadmium (about $85 \%$ ) in usual welding procedure, though original solder about $24 \%$. The fume collected by Cascade Impactor was analysed chemically on each stage, and it was found that the cadmium content in the particles increased with the decrease of particle size. X-ray diffraction analysis of the fume showed that cadmium in the fume is the cadmium oxide. Therefore, it is assumed that workers exposed to the fume from silver solder inhale an enough amount of very small particles whose main component is cadmium oxide, and may suffer from acute cadmium poisoning.
\end{abstract}

The silver solder has become to be used widely by its low melting point and good heat conductivity. This solder is generally composed of silver, cadmium, copper and zinc. Recently, a worker who had been engaged in the welding procedure using this solder in a closed room suffered from a serious acute cadmium poisoning after a while. The authors studied on the fumes in the various welding conditions in order to find out the behaviour of cadmium in the air.

\section{Experiment And Results}

Experimental conditions for welding procedure were arranged similarly as far as possible to the conditions of above mentioned event. The welding was carried out in the small place surrounded by iron plates in the corner of a work room, avoiding the air movement in the room.

At first, a copper plate $(30 \times 20 \times 0.15 \mathrm{~cm})$ was heated with acethylene flame for a while, and the surface of this plate was coated with small amount of flux with toochbrush. Then, another copper plate (a little bits smaller than the former) to be welded was set on it, and welded with silver solder B Ag-1 (Japan Industrial Standard) using the same acethylene flame. This silver solder is composed of silver, cadmium, copper and zinc, and its shape is a thin rod of $1 \mathrm{~mm}$ in diameter. In the welding procedure, this silver solder was consumed at the rate of about $25 \mathrm{~g}$ per minute at $700^{\circ} \mathrm{C}$. The amount of fume produced in this welding condition was assumed to be $5 \%$ of consumed solder from the weight gain of the welded copper plates and weight loss of the solder.

The fume in the air produced by welding was collected by a cascade impactor (Unico) at the distance of $20 \mathrm{~cm}$ from welding point. The air was aspirated 


\section{FUME IN WELDING}

through cascade impactor at $181 / \mathrm{min}$.

The glass fiber papers (Gelman Type A) were set at the first, second, third and fourth stage of the impactor, and the fume was captured on these papers. At the fifth stage of the impactor, a membrane filter (Millipore AA) was set and the fume reached up to this stage was captured thoroughly on it. Naturally, the largest particles of the fume are accumulated at the first stage, and the average size of particles of the fume become smaller and smaller as the order of stage advances.

The average size of particles of the fume captured on each stage is as follows.

the first stage

the second stage

the third stage

the fourth stage

the fifth stage $(\mu)$

13

4

1.5

0.4

$<0.4$

Amounts of the four kinds of metals contained in this collected fume were determined respectively. Cadmium and zinc were determined with dithizone method. ${ }^{12)}$ Copper and silver were determined by means of flame photometry. ${ }^{3}$. And it was confirmed that the metallic composition of the fume differed from the original silver solder remarkably. (Fig. 1). Then, the amounts of four metals in the fume

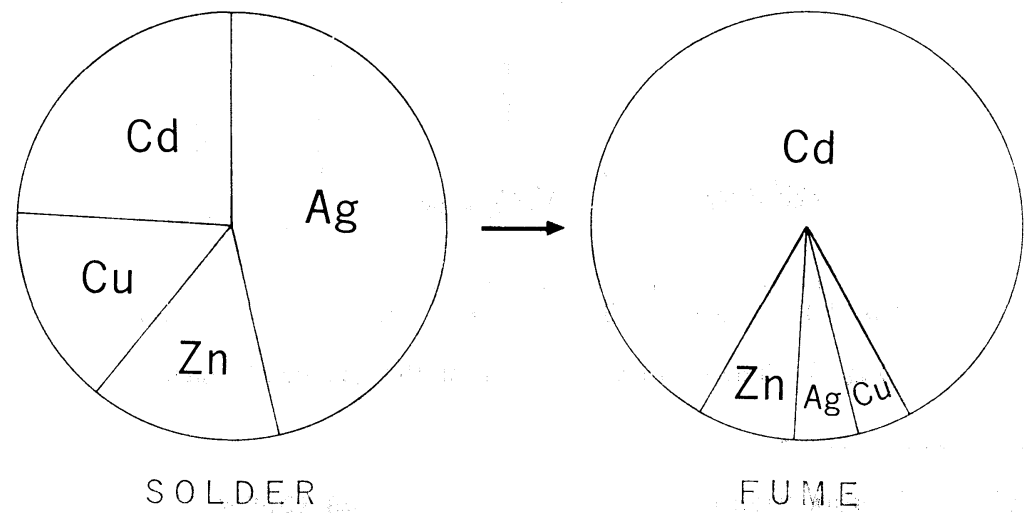

Fig. 1. Metallic compositions of the solder and the generated fume.

captured at each stage were determined respectively. It was found that metallic composition varied greatly with the stages. (Fig. 2). Total amount of four metals contained in the fume captured at each stags remarkably increased as the stage advanced, which was found to be due to the increment of cadmium in the fume.

\section{Discussion}

Metallic composition of the fume differed from that of the original solder greatly. Cadmium was found to occupy a very large part of the fume in amount, and its greater part consisted of very small particles. X-ray diffraction pattern showed that the majority of cadmium in the fume existed as cadmium oxide, and that metallic cadmium was hardly contained in the fume. (Fig. 3). 
N. HARA, K. HOMMA AND S. KOSHI

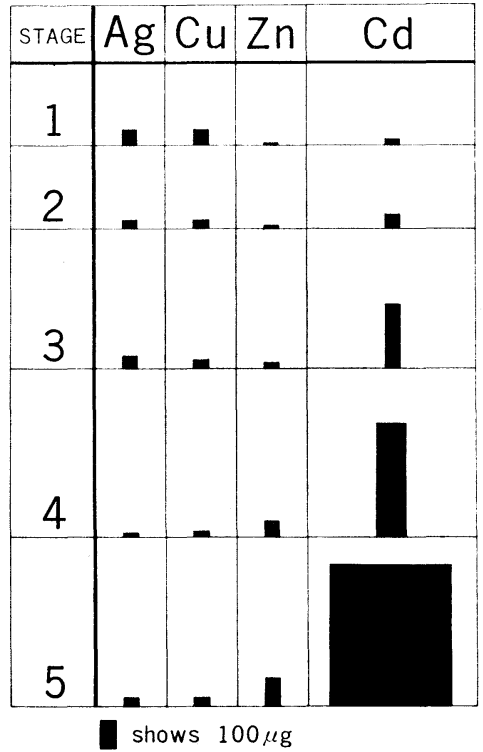

Fig. 2. The change of ratio of metallic composition as the advance of order of stage.
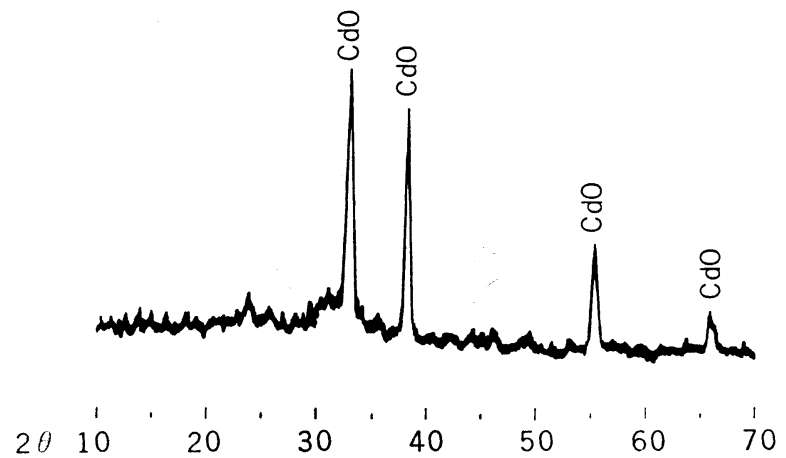

Fig. 3. The diffraction pattern of the generated fume.

\section{(1) Vapour pressure of matallic cadmium}

The physical properties of the four metals are as follows.

$\begin{array}{lllcc} & \mathrm{Cd} & \mathrm{Zn} & \mathrm{Ag} & \mathrm{Cu} \\ \text { melting point }\left({ }^{\circ} \mathrm{C}\right) & 321 & 419 & 960 & 1083 \\ \text { boiling point }\left({ }^{\circ} \mathrm{C}\right) & 767 & 907 & 2152 & 2310\end{array}$

The welding temperature $\left(700^{\circ} \mathrm{C}\right)$ was much higher than melting points of cadmium and zinc, and was near to boiling point of cadmium. So, the vapour pressure of cadmium might be much higher than those of the other three metals during the welding procedure. The vapour pressure of the four metals at $700^{\circ} \mathrm{C}$ are as follows. ${ }^{4}$

$\begin{array}{lc}\mathrm{Cd} & 380 \mathrm{~mm} \mathrm{Hg} \\ \mathrm{Zn} & 58 \mathrm{~mm} \mathrm{Hg} \\ \mathrm{Ag} & \text { negligible } \\ \mathrm{Cu} & \text { negligible }\end{array}$




\section{FUME IN WELDING}

This high vapour pressure may be one of the reasons of the production of a large quantity of cadmium oxide fume.

\section{(2) Nature of sublimation of cadmium oxide}

Except silver, the three metals are oxided easily at the welding temperature $\left(700^{\circ} \mathrm{C}\right)$. So the following materials might exist at the welding point.

silver

\begin{tabular}{|c|c|}
\hline copper & cuprous oxide \\
\hline zinc & zinc oxide \\
\hline cadmium & cadmium oxide \\
\hline
\end{tabular}

These materials are blown into the air or vapourized corresponding to individual vapour pressure during the welding procedure. Of course, cadmium and zinc are in liquid state at the welding temperature. But, only cadmium oxide evaporates very easily comparing with the other materials, as it sublimates into the air at the welding temperature. Cadmium oxide is very stable at $700^{\circ} \mathrm{C}$. (This substance is reduced to metallic cadmium over $900^{\circ} \mathrm{C}$.) The sublimation of cadmium oxide also may be one of the reasons of the production of cadmium oxide fume.

\section{(3) Burning of cadmium}

It was observed clearly that the solder burned with a red flame and that brown smoke was generated simultaneously at the welding point. This combustion showed that metallic cadmium was oxided to cadmium oxide quickly, since the other three metals are hard to burn with flames at this welding temperature. This phenomenon may contribute to the production of cadmium oxide fume, too.

In short, the temperature of melting points and boiling points of silver and copper are high, and their vapour pressures are very small at the welding temperature. So, these metals are small in their amounts in the fume and found mainly in coarse particles.

On the contrary, the temperature of melting points and boiling points of cadmium and zinc are low, and their vapour pressures are large at the welding temperature. Therefore, their amounts in the fume are large and they are mainly found in very fine particles, as these matals principally produce the fume by their vaporization. In addition, cadmium generates a very large amount of fume on account of the above mentioned reasons. These discussion for the high content of cadmium oxide in the fume especially in the fine particles fume are based on the nature of the individual metal, but another approach from the solid solution theory should be tried further.

\section{(4) Silver solder containing nickel}

Cadmium is added to silver solder to lower the melting point of the solder. Though this facilitates the welding procedure, it also emits the fume of cadmium 


\section{N. HARA, K. HOMMA AND S. KOSHI}

oxide into the atmospheric air, which is not desirable for the health of the worker.

There is another silver solder. This solder contains nickel in place of cadmium. The metallic compositions of these two kinds of solders are as follows.

\begin{tabular}{lcccccc}
\hline & $\mathrm{Ag}$ & $\mathrm{Cu}$ & $\mathrm{Zn}$ & $\mathrm{Cd}$ & $\mathrm{Ni}$ & $\mathrm{m} . \mathrm{p} .\left({ }^{\circ} \mathrm{C}\right)$ \\
\hline Solder containing $\mathrm{Cd}$ & $44-46$ & $14-16$ & $14-18$ & $23-25$ & $(\%)$ & $620-760$ \\
\hline Solder containing $\mathrm{Ni}$ & $39-41$ & $29-31$ & $26-30$ & & $1.5-2.5(\%)$ & $780-900$ \\
\hline
\end{tabular}

The amount of generated fume was found to be very small in the same welding procedure performed using solder containing nickel. (Table. 1). In this case, nickel was determined colorimetrically with dimethylglyoxime. ${ }^{5}$

Table. 1. Examples of the amounts of composed metals in the generated fume during the same processes were operated.

\begin{tabular}{c|c|c|c|c|c|c|c|c}
\hline & \multicolumn{4}{|c|}{$\begin{array}{c}\text { Solder } \\
\text { Contained } \mathrm{Cd}\end{array}$} & \multicolumn{5}{|c}{$\begin{array}{c}\text { Solder } \\
\text { contained } \mathrm{Ni}\end{array}$} \\
\hline STAGE & $\mathrm{Ag}$ & $\mathrm{Cu}$ & $\mathrm{Zn}$ & $\mathrm{Cd}$ & $\mathrm{Ag}$ & $\mathrm{Cu}$ & $\mathrm{Zn}$ & $\mathrm{Ni}$ \\
\hline 1 & 45 & 57 & 7 & 23 & 55 & 80 & 25 & 9 \\
\hline 2 & 30 & 30 & 14 & 48 & 13 & 45 & 31 & 4 \\
\hline 3 & 45 & 30 & 21 & 228 & 13 & 38 & 51 & 5 \\
\hline 4 & 13 & 20 & 56 & 805 & 44 & 57 & 100 & 3 \\
\hline 5 & 30 & 30 & 100 & 4170 & 105 & 80 & 110 & 9 \\
\hline total & 163 & 167 & 198 & 5274 & 230 & 300 & 317 & 30 \\
\hline TOTAL & & & 5802 & & & 877 & \\
\hline
\end{tabular}

(unit is $\mu \mathrm{g}$ )

The physical properties of nickel are as follows. The melting point is $1453^{\circ} \mathrm{C}$ and the boiling point is $3177^{\circ} \mathrm{C}$. This metal is stable at higher temperature and is not oxided readily under the welding temperature.

\section{Conclussion}

In the fume generated in the welding procedure using silver solder, a large amount of cadmium oxide was found. Analysis of the fume particles collected by size showed that cadmium content in the fume particles increased steeply with the decrease of particle size. This phenomenon was discussed from the melting point, vapour pressure, sublimation and burning of the component individual metals, though silver solder was a solid solution.

Cadmium fume produces a pneumonitis in acute cases and lung emphysema in chronic cases. It is very important for the prevention of occupational lung disease by cadmium that the large amount fume of very small size which is composed of mainly cadmium is produced already at $700^{\circ} \mathrm{C}$ as seen in this paper. 


\section{FUME IN WEELDING}

\section{References}

1) Saltzman, B. E. (1953). Anal. Chem. 25, 493.

2) Sandell, E. B. (1959). Colorimetric Determination of Traces of Metals, 3rd Ed., p. 941. Interescience Publishers Inc., New York.

3) The Japan Society of Analytical Chemistry. (1956). Kikini Yoru Kagaku Bunseki (Japanese Translation of Willard, H. H., Merritt, L. L. Jr. and Dean, J. A. (1952). Instrumental Methods of Analysis, 2nd Ed., D, Van Nostrand Co., Inc., New York.), 4th Ed., p. 340. Maruzen Co., Tokyo.

4) The Chemical Society of Japan. (1959). Kagaku Binran (Handbook of Chemistry), 6th Ed., p.377. Maruzen Co., Tokyo.

5) Sandell, E. B. (1959). Colorimetric Determination of Traces of Metals, 3rd Ed., p. 668. Interscience Publishers Inc., New York. 